\title{
Assessing the Impact of Interfaith Initiatives
}

\section{Introduction}

In 2011, I began working at the Woolf Institute, which focuses on interfaith relations in the United Kingdom and is based in Cambridge. Shortly after starting the job, the Director of the Institute and I sat down with a professor at Cambridge to ask about pursuing a research project on inter faith dialogue. "Interfaith dialogue is not a field of study," the professor retorted, "it's a practice." Perhaps a year later, I attended a lecture by one of the most well-known scholars of faith and social action in the UK, Adam Dinham. Professor Dinham labelled interfaith dialogue "A pragmatic cobbling together of people who already want to work together”. Referring to the 2007 Labour government initiative Face to Face/ Side by Side, he commented that it had disappeared under the Coalition government "entirely without comment." This initiative, launched by the then Secretary of State for Communities and Local Government, Hazel Blears, was intended to provide an "opportunity to reflect on how Government should support this [interfaith relations], where and in what circumstances interfaith works best and how we can work in partnerships with faith and non-faith-based communities and organizations" (Blears 2007). For Dinham, government consultations like this reflected the interests of "policymakers more than lived reality."1 In practice, without committed leadership, buildings, and basic tenets, forums could only attract those already deeply motivated on a personal level. They offered little for those individuals who rejected communication with other faiths.

I often thought about Professor Dinham's comment when listening to the anxiety and discomfort of interfaith activists in the years following the meeting. These activists frequently repeated an observation that dialogue had become about 'Bagels and Samosas', or food and entertainment, rather than more profound efforts to improve understanding. This disillusionment was echoed amongst policymakers and in policy documents, which cited slow integration of migrant communities and patterns of segregation between minority and majority communities as evidence of the failure of interfaith dialogue. The 2016 Casey Review, a report on ethnic and religious diversity in the UK commissioned

1 From a lecture at the University of Cambridge, Westminster College, 2014.

2 OpenAccess. (C) 2021 Shana Cohen, published by De Gruyter. (cc) BY-NC-ND This work is licensed under the Creative Commons Attribution-NonCommercial-NoDerivatives 4.0 International License. 
by the Conservative government (2016 - 17) and led by Dame Louise Casey, claimed that divisions continued and that "cultural and religious practices in communities that are not only holding some of our citizens back but run contrary to British values and sometimes our laws” (Casey 2016, 5). Indeed, the report lamented the same reduction of interfaith dialogue to 'samosas and bagels' and criticized the government for its neglect of diversity as a salient political and policy issue and thus deserving of innovation and investment. The report states:

Since 2010, cohesion policy has largely been squeezed out, with Government only willing to act exceptionally over the issue, falling well below its stated ambition to "do more than any other government before us to promote integration” ... Government's policy consisted of a relatively small pot of funding going towards small scale exemplar projects such as interfaith dialogue, training curry chefs or cross community social events such as the 'Big Lunch' and 'Our Big Gig'. This has been described to us as amounting to "saris, samosas and steel drums" for the already well-intentioned. These are worthy and enjoyable projects which should continue but they are not enough on their own, nor should they be a substitute for tackling difficult issues $(2016,149)$.

I ask in this chapter if and how interfaith initiatives can be re-examined to determine their value in improving relations between ethnic and religious groups. Do the projects criticized in the Casey Review make any worthwhile contribution to interfaith relations that can inform wider policy efforts? How do we evaluate this contribution?

As the Casey Review and other analyses ${ }^{2}$ have targeted interfaith dialogue and related projects in general, the evaluation framework I discuss here responds in turn, looking across projects to understand the ideas that underpin them and the activities they have inspired. Similar to the widely used evaluation methodology Theory of Change (ToC),this approach analyses assumptions about the expected impact of activities. According to the Center for Theory of Change, Theory of Change dissects the assumptions underpinning a social intervention and its expected impact. Theory of Change is "essentially a comprehensive description and illustration of how and why a desired change is expected to happen in a particular context. It is focused in particular on mapping out or "filling in" what has been described as the "missing middle" between what a programme or change initiative does (its activities or interventions) and how these lead to desired goals being achieved" (Center for Theory of Change 2019). On practical level, pursuing a ToC approach means "first identifying the desired long-term goals and then works back from these to identify all the con-

2 See Hussain (2014) as an example. 
ditions (outcomes) that must be in place (and how these related to one another causally) for the goals to occur."

Rather than focus on the argument underpinning a particular project, as is the case with ToC, I suggest exploring the theories, rooted in theology and philosophy, that have influenced at least the majority of interfaith initiatives and asks if the practical interpretation of these theories has limited the innovation necessary to attract new participants and have a greater impact on relations. The 'theory of change' is thus applied across the field, with programme objectives and expected impact linked directly to external factors like policy and assumptions about how change occurs contextualized within policy debates, resources, and institutional behaviour.

In pursuing this analysis, the chapter draws on some elements of field theory, developed by physicists and extended by social scientists to interpret individual and organizational behaviour. In a review of field theory (2003), John Levi Martin writes that in general, "we may say fields emerge whenever we find a set of institutions that individuals tend to traverse in predictable ways with minimal dislocation of subjectivity. In all cases, the field is something that spans and coordinates institutions by allowing individuals to understand their past, current, and future situations in terms of position, trajectory, and similarity or closeness (Turner 1974, p. 139; cf. Mohr 1994).” (2003, 42) In other words, we can understand individual, or organizational, decisions through locating their position within the field. In other words, they make life choices and understand their own position and that of others in relation to institutions in areas like education, employment, and religion. Martin concludes by stating that, "Field theory disappoints us in remaining vague as to precisely how this occurs, and we hope that it can be eventually surpassed in this regard. Yet it promises the chance of combining rigorous analytic insight with attention to the concrete" $(2003,42)$.

Martin is building on the efforts of a number of social scientists (Bourdieu 1984, 1985; Meyer and Rowan 1977, Fligstein 2001) who want to understand how individuals and organizations make decisions in relation to their context. I am developing upon these ideas but applying them in a very practical fashion to social action. In addition, despite Martin's lament that causality remains vague, I am attempting to explain how fields emerge and are reproduced, or maintain sets of relations and power between actors, and likewise frame how they perceive themselves and each other.

A field of social action could concern any social issue, from adult literacy to unemployment among young people from vulnerable backgrounds to local relations between diverse ethnic and religious groups. A field is constituted by policy - which itself is based on a particular ideological approach or theory of social and economic order; availability and investment of financial and other resour- 
ces; and institutional behaviour. It influences 1) how and which organisations survive, as well as their relations with each other; 2) the designs and expected impacts of specific initiatives; and 3) capacity to innovate or establish initiatives that conflict with predominant ideas and practical activities. Innovation would, in turn, challenge the constitution of the field, and thus the space for differentiation between initiatives is important in assessing the ability of fields to adapt to crises and evolving social issues versus the imperative of reproduction.

For instance, interfaith initiatives have primarily utilized dialogue as their methodology for improving communication and trust. The absence of variation reflects a lack of research and political interest and institutional (religious) support regarding new ideas for better relations. In a 2013 interview in London, an Anglican bishop who had been engaged with interfaith relations told me that dialogue had declined as a priority for the Church of England, in part because the current Archbishop, Justin Welby, was not as interested as his predecessor, Rowan Williams, and in part because younger generations found other local projects more appealing. He stated, "If you have two projects, one to clean up a park and one to understand each other better, I would bet on the park." ${ }^{3} \mathrm{He}$ did emphasize that interfaith relations remained an issue but lacked a framework for communication about diversity. Programmes like Near Neighbours (2011- the present), ${ }^{4}$ which is managed by the Church Urban Fund and financed

3 In fact, parks and other outdoor spaces frequently served as platforms for interfaith cooperation amongst Near Neighbours projects. For example, one project for Near Neighbours involved cleaning up a church garden in London where a violent assault had occurred, in part because the overgrowth shielded the attack. Austerity also provoked cooperation; an interfaith activist in London recounted how she and other residents decided to maintain the local park after the local authority cut funding for maintenance. She and her neighbours borrowed equipment from the authority and maintained the part for two months and then a government contracted service would come every third month.

4 The Near Neighbours programme was established in England in 2011 in order to further cooperation between different ethnic and religious communities. The Near Neighbours programme targeted key locations in England known for high levels of ethnic and religious diversity, and in some cases tensions between groups. There were two stages of Near Neighbours, the first in 2011-13 and the second in 2014-16, with an extension to March 2017 and another in 2018. The programme described its principal objective as bringing "people together who are near neighbours in communities that are religiously and ethnically diverse, so that they can get to know each other better, build relationships of trust, and collaborate together on initiatives that improve the local community they live in.” The two 'key objectives' were to promote greater social interaction and social action. These objectives were achieved through small grants, ranging from $£ 500$ to $£ 5000$, meant to serve as 'seed funding'.

The application process was supported by a local coordinator and local Anglican (Church of England) clergy and deliberately avoided setting targets, encouraging instead the development 
primarily by the Department of Communities and Local Government/Housing, Communities and Local Government, have supported grassroots interfaith initiatives centred on social action. Reflecting on Near Neighbours specifically, he commented, "what is suffering are the dialogical aspects of it. You know, about getting along better."

In sum, because the field has depended on a narrow set of funding bodies and institutions and benefited from only a few policy proposals, it is facing irrelevance without radical renovation. At the same time, because of this status, the field of interfaith relations represents a potentially useful case study for evaluating a field, rather than a single project. Understanding how the field has evolved and why it is in trouble can lead to the transformation it needs to survive. The chapter first describes the research the article relies upon and then examines common interfaith initiatives in the UK to show how individual project evaluation cannot explain the disenchantment cited above, despite evident need. The third section outlines a field approach, suggesting that in the case of interfaith relations, this approach indicates both why the field has remained limited in scale and how it can alter to generate better relations between diverse ethnic and religious groups.

\section{Analysing the Field of Interfaith Relations}

\subsection{Research on Interfaith Relations}

My analysis of a field of interfaith relations is based on four evaluations of Church Urban Fund programmes, including three of the Near Neighbours Grants, and research conducted while at the Woolf Institute on trust and interfaith relations between 2013-2017. I conducted the Near Neighbours evaluations with Kasia Narkowicz and one evaluation of their Together Grants, which support church-based projects fighting poverty (The Woolf Institute 2016), ${ }^{5}$ with John Fahy. The research on the impact of interfaith initiatives on trust between different ethnic and religious communities was conducted largely in London while the evaluations covered different cities in England, including Nottingham, Greater Manchester (Bury and Prestwich), Birmingham, Luton, and East and West Lon-

of projects organic to the area, with goals suited to the particular context and status of local relations between religious groups and between religious and secular residents.

5 The evaluations conducted by Drs Cohen and Narkowicz occurred in five areas: East London, Birmingham, Bradford/Oldham/Burnley area, Luton, Nottingham, Rochdale, Bury and the Black Country. Dr Fahy helped with the Together Grant evaluation in 2015. 
don. The research involved interviews with faith leaders and with organizers of grassroots interfaith projects, overlapping methodologically with the Near Neighbours evaluations.

The interviewees for the evaluations and the more academic study, like Professor Dinham, often expressed cynicism or wariness concerning the impact of explicitly interfaith initiatives. For example, when I mentioned to a young vicar in Tottenham, one of the most diverse areas of London and site of the 2011 riots, that I was going to see Rowan Williams, the then Archbishop of Canterbury, give a talk about interfaith relations, he retorted, "Why?" His view was that interfaith relations occurred when he walked out the door of his parish church. Another vicar categorized interfaith relations as an important academic exercise, away from the daily experience and needs of individuals and communities. In the evaluations, project organizers occasionally observed that practical forms of engagement contributed more to relationship-building than exchanging knowledge about religious beliefs. The latter could come later, after gaining trust and confidence through shared experiences that had more immediate and tangible impact. A vicar in one of the Near Neighbour areas commented that local residents usually thought it was 'great' that the church and the mosque worked together, they were not necessarily interested in joining an interfaith dialogue. However, if the interfaith work was targeted towards meeting the practical needs of the local community, participants expressed more enthusiasm as they perceived greater personal and collective benefit: "I think practical action on something like that, bringing together mosque and church and others is, for me, a more profitable use of near Neighbours really. Because I think often dialogues start at a practical level." The appeal of local activism seemed particularly applicable to younger generations. Remarking on disinterest among youth in interfaith dialogue, a Catholic activist in South London stated flatly, "I don't think I have had any impact on young people at all. The only event that attracts them is the Westminster Interfaith Peace Walk (in June)." He also remarked, "Talking is great but action is very important."

\subsection{How Did the Field Come About?}

Interfaith relations as a field of practice emerged from theology and religious studies, identifying the absence of authentic communication, or exchange of knowledge and subsequence increasing in understanding of the Other, as the critical problem in interfaith relations. The most important theologians for the emerging field of interfaith relations, Wilfred Cantwell and Martin Buber, emphasized the necessity of listening to the 'Other' and taking seriously the beliefs and 
existential meaning inherent to other faiths (Buber 1937; Cantwell 1981). The 'I and Thou' relationship conceived by Martin Buber particularly influenced the format of interfaith forums. He emphasized that authentic communication, where the participants hear what each other says, has no institutional or ideological framework. He wrote:

The relation to the Thou is direct. No system of ideas, no foreknowledge, and no fancy intervene between I and Thou. The memory itself is transformed, as it plunges out of its isolation into the unity of the whole. No aim, no lust, and no anticipation intervene between I and Thou ... Every means is an obstacle. Only when every means has collapsed does the meeting come about (1937, $10-11)$.

In other words, pre-fixed ideas, prejudices, or the historical legacy of encounters should not interfere in the actual, lived, immediate encounter. Diane Eck, a student of Cantwell Smith's and the Director of Harvard University's Pluralism Project, has described interfaith dialogue as having "a range of meanings, all of which involve ways in which we handle our encounters with religious difference-dialogue in daily life, dialogue in learning, dialogue in community, and dialogue in faith and theology" (2017, 27). 'Dialogue' itself signifies “a mutuality of speaking and listening, the kind of communication that rises above, or perhaps penetrates beneath, the chatter of words and the shrill media discussion. It suggests a genuine openness to hearing the concerns of the other in his or her own voice, just as we wish to be heard" $(2017,27)$. Dialogue surmounts the barriers present in everyday communication by directing conversation toward exchange and explicitly focusing attention on the subjective perceptions of participants regarding each other.

\subsection{Evaluating Individual Initiatives}

Statements like Buber's or Eck's have underpinned the development of practical interfaith initiatives, which emphasize the importance of open discussion and listening and of a neutral space that facilitates building trust in the Other. The objectives of these initiatives can remain vague. For instance, Interfaith Week, a national government sponsored initiative organized annually in November by the Interfaith Network, ${ }^{6}$ states as its aims (1) 'strengthening good interfaith relations at all levels', (2) 'increasing awareness of the different and distinct faith communities in the UK, in particular celebrating and building on the con-

6 See the Interfaith Week Network of the United Kingdom (2021). 
tribution which their members make to their neighbourhoods and to wider society' and (3) 'increasing understanding between people of religious and non-religious beliefs'. The activities bringing together members of different faith and belief communities that are run during Interfaith Week, like the national Jewish volunteering event Mitzvah Day, are assumed to be the mechanism of change. Yet, there has been little research on how or if this change happens. Both the impreciseness of objectives amongst existing initiatives, so necessary for evaluation in other fields, and the lack of social research on the long-term implications for attitudes and behaviour of participants in interfaith initiatives have had continued spill over effects on project design. As Renee Garfinkel puts is, "So far there has been very little research on their [interfaith initiatives] effectiveness. This is unfortunate, because those who design and implement interfaith programs need feedback to determine how to maximize their efforts and resources” $(2004,9)$. The creator of Theory of Change (ToC), Carol Weiss, warns against using ToC under these conditions: "Theory-based evaluation is one approach that has a great deal of promise. But trying to use theory-based evaluation is difficult when programs do not have any explicit-or even implicit-theories, when programs are amorphous, or when they shift significantly over time" (Horsch 1998).

Though initiatives like Interfaith Week, or for that matter, most local interfaith forums lack precise objectives and methodologies, over the past twenty years, three specific kinds of initiatives have evolved that are based on explicit theories of change. These are theological, educational, and social initiatives that are often located in public institutions, like schools and universities, or associated with churches and religious organizations. The most prominent form of theological interfaith dialogue is called scriptural reasoning. Founded by retired Cambridge University professor David Ford, scriptural reasoning brings together clergy from different faiths to read religious texts together and relate the teachings to contemporary issues. According to Jeffrey Bailey, scriptural reasoning refers to the following:

[G]roup study of scriptural texts from the three Abrahamic religious traditions. At any given meeting, with roughly equal numbers of each faith represented, passages from the three scriptures are read. A theme (say, debt relief) usually relates the texts together. A few introductory comments about a scripture passage are made by a member of that faith, and then the entire group attempts to understand what the passage is teaching, and how it ought be applied to today's context (Bailey 2006, 37).

In practice, scriptural reasoning as a form of interfaith dialogue consists of four steps: participants identify a theme based on a common concern or interest; they select a relevant passage from each scripture (Muslim, Jewish, and Christian); 
they then read and explain the passage to the other participants; and finally, with the help of a facilitator, participants discuss the passages and reflect on their meaning (Rosecastle Foundation, ND). The outcomes should be greater knowledge of other faiths, especially how the scriptures of each faith speak to contemporary issues and more awareness of how others see one's own faith. The longer-term impact should be moving beyond preconceptions of the other two faiths and the development of relationships that can lead, in turn, to ongoing collaboration to address shared problems.

Whereas scriptural reasoning is often oriented toward clergy, or lay leaders with prior knowledge of texts, dialogue within schools is obviously meant for young people. These projects assume that exposure to the practice and beliefs of other faiths will increase respect and knowledge. As with scriptural reasoning, a facilitator brings together representatives of the different faiths and beliefs to ensure the participants are at ease, or the 'neutrality' evoked in the original theorization of dialogue. In contrast to scriptural reasoning, however, educational dialogue can also refer to culture, and not just religious tenets and texts, and the need for social encounters across diversity.

The Faith and Belief Forum, formerly known as Three Faiths Forum, is the most prominent British organization engaged in educational work. Their projects include linking schools associated with different religious traditions and running workshops. The workshops can bring together a panel of speakers of different faiths and beliefs that is led by a professional facilitator. The speakers share their own experiences of faith and respond to the pupils' questions. In one report, the organization claims that such a workshop helps young people by increasing their knowledge of religion and belief and making them more comfortable with individuals of different religions and beliefs than their own. The workshop should make students appreciate diversity and to seek out relationships with people of different backgrounds. Finally, students who have participated in the workshop should become defenders of religious tolerance and freedom and champions of diversity within British society.

In contrast to the explicitly theological focus of scriptural reasoning or interfaith education based in schools, the third category integrates interfaith relations with another field, most often, social action. The Near Neighbours programme claims two principal objectives: "Social interaction - to develop positive relationships in multi-faith areas i.e. to help people from different faiths get to know and understand each other better," and "Social action - to encourage people of different faiths and of no faith to come together for initiatives that improve their local neighbourhood" [Emphasis adapted from the website] (Near Neighbours 2019). Similarly, the vision of the national Jewish day of volunteering in the UK, Mitzvah Day, is "of Jews and non-Jews coming together to build more cohesive neigh- 
bourhoods and to strengthen civil society” (Mitzvah Day 2021). Sadaqa Day (Sadaqa Day, ND), the Muslim equivalent, is defined as "A date in the calendar when individuals, mosques and other places of worship, schools, women's and community groups, scouts and guides groups can get involved."

When first launched in 2011, the then Secretary of DCLG, Eric Pickles, explained that the purpose of the programme was to overcome the "isolation and misunderstandings which are not healthy for local communities, when by and large, irrespective of creed or faith most people want the same thing, for their neighbourhoods to be better places to live" (Ministry of Housing 2011). On a practical level, Near Neighbours required applications for funding to involve at least two faith groups. Most applications exceeded that, as approximately $90 \%$ of grants awarded included at least three faith groups or those of no faith (Near Neighbours 2017a, 2). Between September 2011 and March 2017, Near Neighbours funded 1433 projects, of which 733 were run by faith groups and 700 by secular community groups (Near Neighbours 2017a, 2).

Overall, Near Neighbours awarded £5,329,894 to 1635 projects across England in this six-year period (Near Neighbours 2017b, 1). The programme operated in nine hubs: Birmingham, the Black Country, West Midlands, Luton, West London, East London, West Yorkshire, Greater Manchester and Lancashire (Near Neighbours 2019). The types of projects that Near Neighbours funded included cooking and archery classes in Luton; exercise and Hebrew classes in Bury; provision of English language skills, a soup kitchen, and a Roma engagement project in Nottingham; and faith tours in Tipton as well as coffee mornings organised on a housing estate for neighbours to get to know each other better. In awarding grants, Near Neighbours emphasized engaging people in projects who might feel excluded from the local community; $50 \%$ of Near Neighbours projects involved unemployed people and a third worked with refugees and asylum seekers (Near Neighbours 2017a, 5).

The timeframe for the grants was relatively short with most grants expected to take place within a year or less from the date of award. ${ }^{7}$ The distribution of grants reflected the existing level of civil society engagement. Where grassroots activism already was strong, such as in Nottingham and Luton, the programme received more applications and consequently, more projects were awarded. In Bury and Tipton the interest was significantly lower, reflecting the lack of community activism, and the grants tended to be awarded to the handful of groups already doing work in the local area.

7 In 2015, a total of 133 projects was funded by Near Neighbours in the five areas: 7 grants were awarded in Tipton, 7 in Bury, 25 in Rochdale, 41 in Nottingham and 53 in Luton 
In the evaluations we conducted, the Near Neighbours projects that were unable to continue cited a lack of funding as the main barrier. There is no data on overall project survival rates, though the evaluations indicated that when the projects survived, it was often because organizations adapted them to accommodate financial constraints. For example, a project based in East London that organized a dance class for men who had tested positive for HIV/AIDS kept shifting the location of the class and finding different instructors because of limited resources. Perhaps more importantly, participants in the Near Neighbours funded projects conveyed that the positive impact on relations remained even if the projects themselves no longer existed. ${ }^{8}$ According to the most recent evaluation of Near Neighbours, which surveyed programme participants in 2018, nearly $50 \%$ of respondents indicated that "because of their involvement with a Small Grant-funded project they have since started volunteering in other community projects” (Bremner 2018, NP).

Yet, returning to the cynicism cited at the beginning of the chapter, if the impact of Near Neighbours was to make volunteering, or implicitly social action and not dialogue, more appealing, what does this say about the potential of dialogue for improving relations across diverse groups? In fact, over the four years of conducting evaluations, projects became increasingly oriented toward social action and not organizing intercultural events or interreligious forums. Organizers openly diminished the role of religion in their activities, preferring to concentrate on social relations and shared interests.

For example, in 2014, tensions in the Middle East meant that Muslim and Jewish groups in Greater Manchester, one of the locations where Near Neighbours operated, would not interact with each other, much less collaborate on a project. A year later, however, young, religious Muslim and Jewish women had organized an exercise class funded by Near Neighbours. They claimed that their project had succeeded because "We are friends, there is no politics, it is so refreshing." Their shared religiosity facilitated cooperation, as participants understood practices like wearing the veil or marrying and having children at a young age. But the organizers were frank in their desire not to discuss religion. Similarly, a rabbi who organized a café with local Muslim leaders in Nottingham described her motivation as practical. Though she had learned about Islam through the project, she stressed the value of collaboration in a social project for understanding, rather than directly engaging in a conversation about religious belief.

8 Ibid. 
Does this wariness of prioritizing religious belief in activities mean that interfaith dialogue may continue to benefit religious and lay leaders or enhance school curricula but not evolve further than a secondary consideration of social action? What can be done, if anything, to extend the scope, and ideally, the impact, of interfaith initiatives?

\section{Assessing the Field of Interfaith Initiatives}

I suggest a more fruitful approach than evaluating single initiatives may be to assess the field itself. This approach would mean, as explained above, asking which initiatives survive and which do not and why not; how organizations relate to each other, specifically, if they compete for scarce resources and/or partner in advocacy and projects; are there prevalent project designs and expected impacts; and is there a space to innovate, or challenge the dominant ideas of the field? Patterns across the field can reveal how the field is reproduced, the effect of this reproduction on kinds of impact, and the necessary changes in initiatives to improve impact.

\subsection{How Has a Field of Interfaith Initiatives Come About?}

Responding to this question entails determining how different factors - policy, institutional behaviour, and availability of material and human resources - influence both the decision-making of organizations and their survival and the design, implementation, and impact of projects. How do these factors influence the conception of the problem across diverse initiatives and the activities they deliver? How do they lend to the dominance or, inversely, marginalization, of particular initiatives? Returning again to the doubts expressed by activists, academics, and policymakers alike about the significance of interfaith dialogue, has the field of interfaith relations relied too heavily on dialogue as a method and likewise, circumscribed capacity to proffer alternatives?

\subsubsection{7/7 and the Rise of Interfaith Dialogue}

In the UK, interest in interfaith dialogue peaked after the July 7, 2005 bombings in London (7/7). Faith-based organizations had already benefited from the Labour government's commissioning agenda, desire to build government-voluntary and faith-based organization partnerships, and support for regionalism. The 
partnership efforts were consolidated under the Local Strategic Partnerships (Communities and Local Government 2009). and the Local Area Agreements ${ }^{9}$ and regionalism institutionalized through the establishment of regional development agencies (Robson, Peck and Holden 2000). Following these policy strategies, the government created regional faith councils to enhance the capacity of faith-based organizations at a local and regional level. For example, the East of England Faiths Council identified its mission as facilitating "the major faith traditions [to be] represented in the region in making input to relevant strategy and issues, to act as a clear point of contact for public, private and voluntary bodies; to support local inter faith and faith activity; and to promote the contribution of faiths to the life and well-being of the region (ND)." In other words, the Council should act as an intermediary, developing the capacity of FBOs and interfaith initiatives to work in partnership and providing advice and guidance to the public sector on how to engage effectively with organizations and indeed, religious identity.

Integration of faith-based initiatives into public sector investment and policy strategies provided more funding and arguably, status, for interfaith work. More specifically, government directives on how to engage with faith-based organizations reinforced the predominance of particular methods of intervention, namely religious literacy and involvement of different faith groups. The Home Office's report "Working Together: Cooperation Between Government and Faith Groups" (2004), which aimed to provide guidelines for closer cooperation between faith communities and the local and national government, instructed government officials to respect faith and belief and learn more about religious diversity. The guidelines for government included 'pursuing faith literacy, enrolling in training, developing networks, and ensuring representation from different faith groups and women, youth, and older people. The implication for interfaith initiatives was that they were expected to deliver activities that provided knowledge of different faiths and their impact was, albeit primarily informally, assessed by the inclusion of representatives of diverse religious groups. The policy agenda and availability of resources thus determined both the activities and the

9 The National Audit Office described the LAAs as "a new form of contract between central and local government and were designed to devolve greater power over public services to local communities." Indicating the ambition of these partnerships, the NAO added, "The Department for Communities and Local Government (DCLG) and the nine Government Offices for the Regions (GOs) have worked to introduce LAAs over the past three years and by April 2007 every local authority in England had one. The amount of public expenditure covered by the agreements is expected to reach around $£ 5$ billion in the next three years” (Beardsley et al. 2007, 2). 
inherent assumptions about their impact, or that encounters aimed at increasing knowledge would lead to better relations between groups.

\subsubsection{Austerity and the Decline of Dialogue}

The decline, even demise, of the regional faith councils, and the emerging identification of interfaith relations with social activism reflect the trajectory of policy support and government funding since the financial crisis in 2007-2008 and the introduction of austerity measures under the coalition government (2010-15). The coalition government (Conservative - Liberal Democrat) ended public sector growth and initiated an era, still ongoing, of continuous cuts to local government and other sources of funding (Lupton, et. al. 2015, 2-4). The government abolished regional development agencies altogether, as well as investment in the regional faiths councils (EEFC closed in 2013) and moved away from the substantive aim of creating public - voluntary sector partnerships in favour of promoting local social action (Tizard 2012).

At the same time, the rapid rise of social problems created by the cuts and economic insecurity, whether from changes to benefits or precarious employment or both, also meant that faith-based organizations were under pressure to address local social demand. The new focus for religious institutions and faith-based organizations was perhaps most noticeable in three trends: government investment in Near Neighbours, the rise of food banks, mostly supported through the Christian organization Trussell Trust, and the expansion of faithbased volunteering days in the UK, which now include Mitzvah Day (Jewish, est. 2005), Sewa Day (Hindu, est. 2010), and Sadaqa Day (Muslim, est. 2015). Near Neighbours received $€ 5$ million for the first stage, launched in 2011, and $£ 4.5$ million more for another stage that began in 2014 and was extended in 2016 for another year, and then, most recently, £1.5 million in 2019.

Private foundations did not elect to substitute for public investment as it diminished, shying away themselves from prioritizing interfaith relations. The Interfaith Network, a national umbrella organization, continued to receive government funding, in addition to member fees. The other prominent national interfaith organizations, like Three Faiths Forum (3FF/ Faith and Belief Forum, have relied on relationships with a small number of British and foreign private foundations and individual donors, as well as occasional support from organizations like the British Council and government departments. The Cambridge Interfaith Programme (CIP), which was founded by Professor David Ford, is housed at the University of Cambridge and has received private funding as well as funding from the American-based Coexist Foundation (Coexist Foundation 2019). 
For the majority of interfaith initiatives, the loss of government and philanthropic support represented more than access to material resources. It was also politically symbolic, just as the past interest in interfaith relations gave legitimacy to initiatives. As a vicar based in London explained to me around 2013, "At one point there were a lot of interfaith forums. This has diminished because of the funding." However, he also added, "It's not just the funding. The previous government was really into the notion of faith communities working together and they thought, all the sort of spin was they could impact hard to reach communities. All that was understood is that they had a bit of power. It is certainly completely out of fashion now except for Near Neighbours.” On a practical level, the notion inherent in interfaith forums that knowledge of other religions and social encounters, facilitated by shared holidays and other events, would generate familiarity, trust, and cooperation, had lost the confidence of policymakers.

\subsection{The Implications for Interfaith Initiatives}

\subsubsection{The Few Organizations that Have Survived Have Relied Primarily on Established Private Sources of Funding and Have Offered a Consistent Range of Activities}

The organizations engaged in interfaith relations that have survived in the postfinancial crisis period, or over the past decade, have been those in existence for over several decades, and thus relatively well established even before the spike in government interest after the $7 / 7$ attacks. These organizations are linked to stable sources of funding, especially private donors and universities. Significantly for the field, they have maintained the same activities, for instance, the Cambridge Interfaith Programme (est. 2002) has always centred its work on scriptural reasoning. 3FF/Faith and Belief Forum (est. 1997) primarily concentrates on educational activities and the Interfaith Network (est.1987), which does receive government funding, runs activities like Interfaith Week, which is held in November and consists of interfaith activities around the country, and organizes meetings between religious and lay leaders and community representatives. With the closure of regional faiths councils after the financial crisis in 2007-08, the Interfaith Network became the only body able to bring together members of different communities for formal activities.

Conversely, in my research, the local interfaith forums still in existence must rely on volunteers who often possess a long history of involvement in interfaith relations. For example, a Catholic interfaith activist who I interviewed in 2014 had led a forum for interfaith dialogue in South London for decades. Describing 
his role, he said, "I have got a lot of people together. I have improved communications ... I have very patiently built up my group at the Cathedral. I had a meeting the other week and 30 people came up to me. I have become known. I wanted to put on the map that the Catholic Church is very committed to interfaith.” The Muslim-Jewish Forum in Manchester (est. 2004) also depends on voluntary leadership of local Muslim and Jewish activists. Similarly, projects funded by Near Neighbours, at least in the evaluations I conducted, struggled for other funding unless supported by an institution or organization. For example, a mother-toddler group run through the Salvation Army lasted past the NN funding because the Salvation Army assumed the costs.

\subsubsection{Collaboration is Beneficial in a Resource-Limited Field}

The well-established organizations mentioned above, with the exception of the Inter Faith Network, have regularly collaborated. They form a small cluster (3FF/Faith and Belief Forum, Coexist, CIP, and Goldsmiths) able to seek out new areas of influence through training and other activities and, in effect, affirm each other's position within the field. As mentioned above, CIP has partnered with Coexist Foundation and with 3FF/Faith and Belief Forum to establish religious literacy projects in the Middle East. CIP has also collaborated with Coexist on a number of leadership training and cultural projects (Cambridge Inter Faith Programme 2021) and shared donors and staff members. CIP and Coexist have partnered with Adam Dinham at Goldsmith's University, for instance, on religious literacy training for Ernst and Young (Coexist House 2017).

\subsubsection{There is Little Variance within the Field in How the 'Problem' of Interfaith Relations is Conceived}

The resemblance between mission statements of interfaith initiatives, regardless of size, illustrates how dominant the conception is within the field that greater understanding in a neutral venue can overcome tensions and lead to positive relationships. For instance, the Birmingham Council of Faith's (est.1974) website states that they "organise events throughout the year to facilitate harmonious relations between people of different faiths in the city. This includes promoting the study of all religions so that the followers of one religion may have a better understanding of the other religions and be alert of issues, peace, justice and tolerance in our city (2021)." The Bedford Council of Faiths (est. 2004) lists the following aims: "to promote religious harmony, dispel ignorance and prejudice 
about beliefs, foster religious understanding and mutual respect and encourage friendships across religious boundaries (Bedford Council of Faiths 2020)." Similarly, The Inter Faith Network states that they work with "faith communities, inter faith organisations, educators and others to increase understanding and cooperation between people of different faiths and to widen public awareness of the distinctive religious traditions in the UK (2021)." The Faith and Belief Forum creates "spaces in schools, universities, workplaces and the wider community where people can engage with questions of belief and identity and meet people different from themselves. Enabling people to learn from each other in this way is often the most effective way to tackle ignorance and challenge stereotypes - and create understanding and trust between people (2021).” In sum, despite differences in longevity, location, and resources, initiatives make the same assumptions about intervention and impact.

\subsubsection{Innovation Has Been at a Grassroots Level and Primarily Unsustainable}

The grassroots nature of projects funded by Near Neighbours or local interfaith forums means that they often are time-limited, volunteer-led, and dependent on manipulation of scarce resources. For instance, a sewing circle for migrant women in London benefited over several years from government support and Near Neighbours funding but still faced closure in 2017. The staff had stopped receiving salaries to help the organization survive but it was unclear it would last. At the same time, the initiative had succeeded in accessing highly marginalized groups, including migrants, asylum seekers, and women with disabilities by running sewing circles in a high street store. The project organizer related how a Muslim woman came to one of the circles dressed in scant clothing. The other women asked her why she was dressed, at least for them, inappropriately, and she responded that she had accepted the only clothing on offer at the shelter where she was staying. The other women responded by finding clothing for her to wear. The story was intended to demonstrate how relationships, and forms of social support, had emerged from the circles. Its demise would mean that a platform for generating relationships, especially amongst these populations, would disappear.

Two other initiatives, mentioned above, brought together Muslim and Jewish leaders in Nottingham to run a café for low-income residents and religious Muslim and Jewish women seeking a single-sex exercise class where their attire and life decisions, such as early marriage and children, would not be questioned. Again, the initiatives relied upon volunteers and local contributions. Yet, their impact extended beyond interfaith relations in an explicitly religious sense, as 
they encouraged interaction between two communities subject in their relationship to ongoing conflict in the Middle East.

\subsection{Reconceiving the Field}

Reconceiving a field involves responding to external factors that are stymieing constructive change, such as declining funding opportunities and shifting policy priorities. Reconceiving the field also means challenging interfaith initiatives to contemplate a new conceptualization of their work and to renew themselves as organizations. Moving away from Buber's emphasis on neutrality, the effort to mobilize resources in order to help others locally could be interpreted as the 'living will' that Emmanuel Levinas, a philosopher-theologian, highlights when analysing the work of another Jewish theologian Franz Rosenzweig (1990). Levinas writes that Rosenzweig wanted an alternative interpretation of the individual's position in history to that of philosophers like Hegel (or Marx), where "the significance of a work is truer in terms of the will that wished it into being than the totality into which it is inserted ... the living willing of will is indispensable to the truth and understanding of the work" $(1990,200)$.

Assigning the effort to help others its own value, even transcendent to the actual 'help' itself, resembles Kant's Formula for Humanity as well, where Humanity is a means and an end. (Korsgaard 1986) Of course, both philosophical considerations lack reference to religious belief, but then much of the intention of grassroots activism is to acclimate residents to cooperation across diversity and then encourage gaining an understanding. The point is that the prioritization of religious belief does not hold in grassroots activism, but rather, has to be integrated into a conceptualization of how individual action to benefit others can alter attitudes and relationships. As a vicar working at a church in East London said to me in 2016, the renewal of the Church of England, long in decline, would only come about from connecting the practice of community organizing to theorizing a different social role for the Church as an institution. He explained that the Church was "Moving in a positive direction but largely what we are about as the Church of England is gathering people together to serve their kind of needs. When we talk about reaching out, what we are talking about is growing our church. There is a lot of evidence that one of the features of growing a church is to be socially engaged." He argued that:

What is really required is a theology of social engagement that is.... about what we are about as Christians. That is one of the positive things about this austerity period, churches have gotten their hands dirty ... people have not been doing stuff but have started to think 
this feels like real Christianity. This gives me the opportunity to make connections, what society is like, how do I relate to it, how do I share love.

The 'love' he wants to share reflects his belief but also recognition of humanity in everyone, regardless of their belief. In Kant's terms, humanity is 'unconditionally good'. As Korsgaard writes, "The possession of humanity and the capacity for good will, whether or not that capacity is realized, is enough to establish a claim on being an unconditional end" $(1986,197)$. The objective of good will toward others is for those individuals to realize their own capacity through the interaction, in essence, acknowledging through social relations the humanity of all participants.

Engaging theoretical ideas should not be beyond the work of practitioners and applied research, as this engagement prevents obscuring often ideologically driven assumptions within policy about individual behaviour, inequality, social obligations, and so on. Thinking theoretically also allows for critiquing language, such as 'service user', which again neglects the critical importance of social relations to the quality and effectiveness of intervention (Oxfam 2009; Cohen 2014). What constitutes 'theory' may differ by field, for instance interfaith initiatives are derived from theological and philosophical analysis. More importantly, negotiating the relationship between ideas and practice diminishes the boundary between the two, as the two forms of knowledge, academic and practical, respond to the other.

Redesigning interfaith activities that go beyond neutral forums and religious literacy could, if premised on the will and effort to help others and recognition of a common humanity, emphasize the process of cooperation. Buber does offer guidance for how the relationships developed within the cooperation can be conceptualized. He notes that relations between I and Thou develop in the present, and that the present is "continually present and enduring." Other relations, or not in the present, are instead characterized by "cessation, suspension, and breaking off and cutting clear and hardening, absence of relation and of present being” (12-13). These terms imply closure and stagnation, rather than continued interaction and spontaneity. ${ }^{10}$

Following this explanation of Buber's, the process of cooperation could both account for specific relationships within the local context and provide a 'standardized' framework across interfaith initiatives. Cooperation would provide a foundation for continuous interaction, respect, and openness, with expectations based on participation and shared will. Adopting this flexible, contextualized

10 See also Vollmer (2013). 
approach to interfaith work means that some initiatives could offer religious literacy, perhaps because they are located in areas where faith communities are segregated, and others would assume existent knowledge and thus stress other areas of work like public institutional reform and rights. Concentrating on cooperation as the project design would ideally increase practical impact and elevate public awareness of the values of openness and respect the field represents. Impact assessment would continue to be based on participation rates across diverse groups, but it would evaluate types of participation as well, commitment of time and resources, the effects of cooperation on quality of life and emotional well-being, translation into advocacy, and interreligious understanding.

Reconceiving a field of social action involves responding to external constraints and opportunities in instigating change across initiatives and likewise, redesigning initiatives to address problematic trends characterizing the field and limiting impact. In the case of interfaith initiatives, effective change in attitudes and behaviour may come not just through participation in collective local activism but also by approaching faith and belief from a more complex philosophical perspective. In other words, behaviour toward the Other may relate more to ethics, and then understanding of religious difference, rather than just understanding. More specifically, devising a response entails 1) rethinking the theoretical and philosophical ideas that have informed design, management, and evaluation and 2) integrating these ideas with a new approach to practice that addresses characteristics of the field like the sustainability of a particular type of organization or the range of diversity in service design. Finally, the reconception demonstrates for funding bodies and policymakers, as well as relevant institutions like the Church of England, needed support.

\section{Conclusion}

In this chapter, I have offered a potential direction for assessing interfaith initiatives by analysing the field itself, or how it has become sustainable in its current form, the predominant conception of the problem and appropriate responses, categorization of impact, divisions and contradictions within the field, and trends in participation. The assessment should reveal potential for reconceiving the field and individual project aims, designs, and impact. In brief, the paper makes the following recommendations:

1. Conduct evaluation at the level of a 'field' to understand constraints and opportunities regarding interfaith initiatives. 
2. Focus on indicators like the diversification within the field; distribution of resources across different-sized projects and organizations; and collaboration and cooperation between organizations to analyse how a field is constituted and is sustained, as well as the kinds and depth of impact of specific projects.

3. Likewise, connect policy, institutional behaviour, and access to material resources with project implementation and delivery and the experience of participation in order to understand the impact of a field and how it needs to change.

4. Encourage shared information, as with collective impact and other models, across organizations but not just to have consistent approaches to evaluation, in part to influence policy, but also to rethink the field itself and the role of policymakers, service users, staff, and other stakeholders in designing future interventions.

\section{References}

Abu-Nimer, Mohammed. 2004. "Religion, Dialogue, and Non-Violent Actions in Palestinian-Israeli Conflict," International Journal of Politics, Culture, and Society 17(3): 491-511. ISSN: 0891-4486

Baily, Jeffery W. 2006. "New Models for Religion in Public: Interfaith Friendship and the Politics of Scriptural Reasoning." Christian Century 123 (2006): 36-42. https://www.in terfaith.cam.ac.uk/resources/scripturalreasoningresources/newmodels

Balibar, Etienne. 2015. "Trois mots pour les morts et pour les vivants," Liberation, 11 January 2015. http://www.liberation.fr/debats/2015/01/09/trois-mots-pour-les-morts-et-pour-lesvivants_1177315

Beardsley, Grace et al. 2007. Local Area Agreements and the Third Sector: Public Service Delivery. London: National Audit Office. https://www.nao.org.uk/wp-content/uploads/ 2007/06/NAO_Local_Area_Agreements.pdf (2007)

Bedford Council of Faiths. 2020. "About Us.” https://www.bcof.org.uk/about-us

Birmingham Council of Faiths. 2021. https://bhamfaiths.org.uk

Blears, Hazel. 2017. "Interfaith Dialogue and Social Action: Communities and Local Government written statement - made on $17^{\text {th }}$ December 2007." They work for you, 17 December 2007. https://www.theyworkforyou.com/wms/?id=2007-12-17b.83WS.1

Bourdieu, Pierre. 1984. Distinction. Cambridge, MA: Harvard University Press, Trans Richard Nice.

Bourdieu, Pierre. 1985. "The Genesis of the Concepts of Habitus and of Field." Sociocriticism 2:11-24.

Bourdieu, Pierre. 1987. “What Makes a Social Class?” Berkeley Journal of Sociology, 32(1987):1-17.

Bremner, Stephen. 2018. Near Neighbours Small Grant Fund 2016/17 Evaluation Final Report. February 2018.

Buber, Martin. 1937. I and Thou. Edinburgh: T and T Clark, Trans Ronald Gregor Smith. 
Cambridge Interfaith Programme. 2021. "Our Approach to Inter-Faith Encounters.” Accessed 8 March 2021. https://www.interfaith.cam.ac.uk/aboutus/cipapproachinterfaithencounters Cantwell Smith, Wilfred. 1981. On Understanding Islam. London: De Gruyter.

Casey, Dame Louise. 2016. The Casey Review: A review into opportunity and integration. London: Department for Communities and Local Government.

Center for Theory of Change. "Center for Theory of Change: Setting Standards for Theory of Change.” 2019. Accessed 24 July 2019. www.theoryofchange.org

Coexist Foundation. 2021. About Coexist. Accessed 8 March https://www.coexistfoundation. org/about

Coexist House. 2017. "What we are up to in our House without Walls." Accessed 8 March 2021. https://www.coexisthouse.org.uk/coeixst-house-without-walls.html

Cohen, Shana. 2014. "The Politics of Social Action in Morocco," Middle East Topics and Arguments, Vol. 1, No 2.

Cohen, Shana. 2016. Social Action and Social Change. Boulder, CO: Paradigm Press.

Department for Communities and Local Government. 2009. Planning Together: Updated practical guide for local strategic partnerships and planners. London: Department for Communities and Local Government. Published April 2009. https://www.gov.uk/govern ment/uploads/system/uploads/attachment_data/file/8334/1193492.pdf

Garfinkel, Renee. 2004. "What Works?: Evaluating Interfaith Dialogue Programs," Washington, DC: United States Institute of Peace.

Davies, Siriol. 2007. An Evaluation of Different Models of Interfaith Activity, London: South London Inter Faith Group.

Greene, Jennifer. 2005. "A value-engaged approach for evaluating the Bunche-Da Vinci Learning Academy. New Directions for Evaluation 2005(106): 27-45. https://doi.org/10. 1002/ev.150

Horsch, Karen. 1998. "Interview with Carol Weiss." The evaluation exchange: a Periodical on Emerging Strategies in Evaluation IV(2). Harvard Family Research Project. https://archive. globalfrp.org/evaluation/the-evaluation-exchange/issue-archive/evaluation-in-the-21stcentury/interview-with-carol-h.-weiss

Faith Belief Forum. 2021. “About Us.” Accessed 8 March 2021. https://faithbeliefforum.org/ about/who-we-are/

Hussain, Aamir. "The Challenges of Interfaith Dialogue," Huffington Post. Updated 17 March 2014. https://www.huffpost.com/entry/the-challenges-of-interfa_b_4581918

The Inter Faith Week Network for the United Kingdom. 2021. "Inter Faith Week." Accessed 8 March 2021. https://www.interfaithweek.org

East of England Faiths Council. ND. East of England Faiths Council. Accessed 24 July 2019. http://www.eefaithscouncil.org.uk/

Fitzpatrick, Jody L. 2012. "An introduction to context and its role in evaluation practice." New Directions for Evaluation 2012(135): 7-24. https://doi.org/10.1002/ev.20024.

Fligstein, Neil. 2001. "Social Skill and the Theory of Fields." Sociological Theory 19:105-25.

The Inter-Faith Network for the United Kingdom. 2021. Accessed 8 March 2021 https://www.in terfaith.org.uk/about/mission-vision-and-values

Katz, Michael. 1995. Improving Poor People. Princeton, NJ: Princeton University Press.

Korsgaard, Christine. “Kant's Formula of Humanity." Kant-Studien 77(April 1986): 183-202.

Lazar, Sian. 2004. "Education for Credit. Development as Citizenship Project in Bolivia." Critique of Anthropology, 24 (3): 301-319. 
Levinas, Emmanuel. 1990. Difficult Freedom: Essays on Judaism. Baltimore, MD: Johns Hopkins University Press, Trans Sean Hand.

Lupton, Ruth et. al. 2015. "Social Policy in a Cold Climate: Summary Research Report 4: The Coalition's Social Policy Record 2010-2015.” Nuffield Foundation. Published January 2015. http://www.nuffieldfoundation.org/sites/default/files/files/RR04_SUMMARY.pdf

Manell, Jenevieve. 2012. “'It's just been such a horrible experience:' Gender mainstreaming in South African organisations." Gender and Development 20(3): 523-434.

Martin, John Levi. 2003. "What is Field Theory?" American Journal of Sociology (109)1: 1- 49. Meyer, John W., and Brian Rowan. 1977. "Institutionalized Organizations: Formal Structure as Myth and Ceremony." American Journal of Sociology 83:340-363.

Ministry of Housing, Communities \& Local Government. 2011. "Launch of Near Neighbours Programme.” Published 4 November 2011. https://www.gov.uk/government/news/ launch-of-near-neighbours-programme

Mitzvah Day. 2021. “Mitzvah Day - Vision and Mission.” Accessed 8 March 2021. https://mitz vahday.org.uk/vision-mission/

My Sadaqa Day. ND. “About Sadaqa Day”. Accessed 24 July 2019. https://mysadaqaday.org/ about-sadaqa-day

Mollov, Ben et al. 2004. "Contact, Gender and Arab-Jewish Inter-religious Dialogue Evaluated" (Prepared for Annual Meeting of International Association for Conflict Management Pittsburgh, U.S.A., 2004).

Near Neighbours. 2017a. Impact Report 2011-2017. Near Neighbours. Accessed 8 March 2021. https://static1.squarespace.com/static/5a68889a90bade540b4da177/t/ 5b239001aa4a99a4bb1ac216/1529057287026/Near+Neighbours+Impact+Report.pdf

Near Neighbours. 2017b. Key Facts 2011-2017. Near Neighbours. Accessed 8 March 2021. https://static1.squarespace.com/static/5a68889a90bade540b4da177/t/ 5b23905c1ae6cf9c5343864f/1529057372234/Key+Facts+2011-2017.pdf

Near Neighbours. 2019. Accessed 24 July 2019. https://www.near-neighbours.org.uk

Neufeldt, Reina C. 2011. “Interfaith Dialogue: Assessing Theories of Change," Peace \& Change 36(3): 344-5. ISSN: 1468-0130

O’Connor, Alice. 2001. Poverty Knowledge: Social Science, Social Policy and the Poor in 20th Century U.S. History. Princeton, NJ: Princeton University Press.

Oxfam. 2009. Blind Optimism. (A Briefing Paper). Published February 2009. https://oi-filesd8-prod.s3.eu-west-2.amazonaws.com/s3fs-public/file_attachments/bp125-blind-opti mism-0902_14.pdf

Robson, Brian, Jamie Peck and Adam Holden. 2000. "Regional Development Agencies and local regeneration.” Joseph Rowntree Foundation. Published 17 May 2000. https://www. jrf.org.uk/report/regional-development-agencies-and-local-regeneration

Rog, Debra J. 2012. "When background becomes foreground: Toward context-sensitive evaluation practice." New Directions in Evaluation (2012)135: 25-40.

Rosenvallon, Pierre. 2011. Societe des Egaux. Paris: Seuil.

Rosecastle Foundation. ND. "What is Scriptural Reasoning?" Rosecastle Foundation and The University of Cambridge Inter-faith Programme. Accessed 24 July 2019. http://www.scrip turalreasoning.org/what-is-scriptural-reasoning.html\#

Swartz, David. 1996. Bridging the Study of Culture and Religion: Pierre Bourdieu's Political Economy of Symbolic Power." Sociology of Religion (57)1: 71-85. 
Thorley, Sarah. 2007. Improved Understanding of South London's Multi-Faith Situation. London: South London Interfaith Group.

Tizard, John. 2012. "Time for Local Community Leaders to Collaborate and Put Place First." Huffington Post. Published 5 November 2012. http://www.huffingtonpost.co.uk/john-ti zard/local-strategic-partnership_b_2068953.html

UNDP. 2009. Handbook on Planning, Monitoring, and Evaluating for Development Results. Accessed 8 March 2021. http://web.undp.org/evaluation/handbook/get_handbook.html

Vollmer, Hendrik. 2013. The Sociology of Disruption, Disaster, and Social Change. Cambridge: Cambridge University Press.

Weiss, Carol. 1997. Evaluation: Methods for Studying Programs and Policies. New York: Prentice Hall. ISBN: 978013309725

The Woolf Institute. 2016. Near Neighbours Evaluation Report. Cambridge: The Woolf Institute. 